Canadian University Music Review

Canadian University Music Review

Revue de musique des universités canadiennes

--> Voir l'erratum concernant cet article

\title{
Advanced Uses of Mode Mixture in Haydn's Late Instrumental Works
}

\section{Howard Irving et Herbert Lee Riggins}

Volume 9, numéro 1, 1988

URI : https://id.erudit.org/iderudit/1014925ar

DOI : https://doi.org/10.7202/1014925ar

Aller au sommaire du numéro

Éditeur(s)

Canadian University Music Society / Société de musique des universités canadiennes

ISSN

0710-0353 (imprimé)

2291-2436 (numérique)

Découvrir la revue

Citer cet article

Irving, H. \& Riggins, H. L. (1988). Advanced Uses of Mode Mixture in Haydn's Late Instrumental Works. Canadian University Music Review / Revue de musique des universités canadiennes, 9(1), 104-135. https://doi.org/10.7202/1014925ar

All Rights Reserved @ Canadian University Music Society / Société de musique des universités canadiennes, 1988
Ce document est protégé par la loi sur le droit d'auteur. L’utilisation des services d'Érudit (y compris la reproduction) est assujettie à sa politique d'utilisation que vous pouvez consulter en ligne.

https://apropos.erudit.org/fr/usagers/politique-dutilisation/ 


\section{ADVANCED USES OF MODE MIXTURE IN HAYDN'S LATE INSTRUMENTAL WORKS}

\section{Howard Irving \& Herbert Lee Riggins}

It is a commonplace observation that at many points in the history of tonal music, contemporaneous theorists have been hard pressed to keep pace with the more progressive efforts of imaginative composers. This phenomenon is particularly noticeable in theoretical writing of the late eighteenth and early nineteenth centuries, in which theorists were faced with the task of explaining an expanding vocabulary of chromatic operations which could not be rationalized satisfactorily from the existing foundation of theoretical concepts. In fact, as Matthew Brown observes in his recent article in the Journal of Music Theory, some modern speculative theorists have been forced to divide the so-called period of common practice into, on the one hand, "classical diatonic tonality" with one set of rules and assumptions and, on the other, "nineteenth-century chromatic tonality," in which fundamentally new assumptions must be made. 1

The following is an attempt to come to a greater understanding of this divergence in harmonic practice by examining the use of certain harmonic procedures in the music of Joseph Haydn, whose later works stand near the intersection of these two epochs, and by considering the efforts of theorists of the late eighteenth century to rationalize Haydn's progressive harmonic language.

$1 \quad$ Matthew Brown, "The Diatonic and the Chromatic in Schenker's Theory of Harmonic Relations," Journal of Music Theory 30 (1987), 2; Gregory Proctor, "Technical Bases of Nineteenth-Century Chromatic Tonality: a Study in Chromaticism," (Ph.D. dissertation, Princeton University, 1977), p. iii. 
Haydn's uses of third-related keys, especially as they occur in or among the movements of a multi-movement work, cannot easily be explained using eighteenth-century conceptions of key relation. The inadequacy of existing theory is graphically illustrated in August Kollmann's Essay on Practical Musical Composition, ${ }^{2}$ in which the author attempts unsuccessfully to rationalize certain key relationships among the movements of Haydn's piano trios Hob.XV:27-29.

It is possible, however, by examining the evolution of Haydn's approach to the use of third-related keys to speculate on a rationale the composer himself may have had in mind in the use of these key relationships. Obviously there are dangers in this line of approach: Haydn was not a theorist and he did not feel compelled to articulate any specific theoretical system either in writing or in conversations with his early biographers. Although the composer's ultimate intentions can only be a matter of speculation, the body of music from which this concept of harmonic relations can be inferred is substantial and the evolution of Haydn's methods can be traced clearly.

This paper considers the issue of Haydn's third-related keys in three ways: first, by examining briefly the writings of certain late eighteenth-century theorists; second, by proposing a new theory that is suggested by Haydn's actual practice; and finally, by tracing the evolution of this system in Haydn's later instrumental works.

In his recent article, "The New Modulation of the 1770's: C. P. E. Bach in Theory, Criticism, and Practice," Richard Kramer sheds new light on a revised edition of Bach's Versuch über die wahre Art das Clavier zu spielen that was published in 1797 by Engelhardt Schwickert. ${ }^{3}$ In a supplement that was added by Bach to the last chapter of his treatise the subject of modulation to distant keys is discussed and

Augustus Frederic Christoph Kollmann, An Essay on Practical Music Composition (London, 1799; New York: Da Capo Press, 1973).

Richard Kramer, "The New Modulation of the 1770's: C.P.E. Bach in Theory, Criticism, and Practice," Journal of the American Musicological Society 38 (1985), pp. 551-592. 
examples from certain works of Bach-identified for the first time in modern writing by Kramer-are given as illustrations. In the course of his discussion of a Rondo in C major (which Kramer identifies from the collection Clavier-Sonaten nebst einigen Rondos für Kenner und Liebhaber. . . W.56), Bach offers a rationale for modulations to keys that are not closely related: 4

When I played this rondo, I was asked . . . "Who but yourself would dare go directly from C major to E major?" I replied, "Anyone can and will assuredly do it who knows that $\mathrm{E}$ is the dominant of $\mathbf{A}$, and that $\mathbf{A}$ minor is very closely related to $\mathbf{C}$ major."

This rationale for distant key relations is common among theorists of the second half of the eighteenth century. For example, in Die Kunst des reinen Satzes in der Musik (1771-1779), Johann Philipp Kirnberger writes that when it is "occasionally ... necessary to modulate quickly to keys that are remotely related to the main key," it is usually accomplished in this way: 5

One takes the dominant of one of the keys to which one can go directly from the main key [i.e., the dominant of one of the five closely-related keys] and, without closing from there to its tonic, reinterprets it as a tonic triad, from which it is now possible to progress by one step to any triad contained in its scale.

By way of illustration, Kirnberger shows that it is possible to modulate from $\mathrm{C}$ major to F-sharp major by first going to the dominant of the closely-related key of e minor. As he describes it, "if one now conceives of this B major triad as the principal tonic, it is possible to go directly

Ibid., p. 552.

5 Johann Philipp Kirnberger, The Art of Strict Musical Composition, trans. David Beach and Jurgen Thym (New Haven: Yale University Press, 1982), p. 149. 
from there to the chord of its dominant (F-sharp major) or its mediant (D-sharp minor)."6

When these theories of key relationship are applied to the tonalities of movements within cycles as opposed to key areas within movements, some problems arise. In August Kollmann's discussion of unusual key relationships among movements of sonata cycles in his Essay on Practical Musical Composition (1797), he cites examples from a group of late piano trios by Haydn that had recently been published:

... I must mention four cases of abrupt changes of the key from one movement to another, which are found in Haydn's Sonatas Op.75 [i.e., Hob.XV:27-29]. ${ }^{7}$ The first is in Sonata I [Hob.XV:27], where the first movement is in C major, and the second in A major. This change is allowable, according to the rules of abrupt modulation by omission, in my Essay on Harmony, Chap.X, [paragraph] 13, for C is the key, and the triad of $\mathrm{A}$ the leading chord [dominant] to a related key; but $\mathrm{A}$ is retained and made a substituted key. ${ }^{8}$

It is important to keep in mind the intellectual frame of reference of this treatise. Kollmann normally structures his arguments on the bedrock of empiricism: for him the ultimate test of the legitimacy of any procedure is found by comparing it with the works of the great composers. Since he has already identified Haydn as one of these great composers, Kollmann has a strong incentive to find a way to justify these (for that time) unusual key relationships.

The rationale offered by Kirnberger, on whose theories Kollmann's work is based, offers the needed justification. One begins as if modu-

$6 \quad$ Ibid., p. 552

$7 \quad$ Hob.XV: $27-29$ were published as Op. 75 in 1797 according to H.C. Robbins Landon, Haydn: Chronicle and Works, vol. 4, The Years of "The Creation" 1796-1800 (Bloomington, Indiana: Indiana University Press, 1976), p. 199.

Kollmann, An Essay on Practical Musical Composition, p. 10. 
lating from the key of $\mathrm{C}$ major to the key of $\mathrm{d}$ minor, a closely-related (and thus legitimate) destination. In the course of establishing the key of $\mathrm{d}$ minor one naturally arrives first on its dominant, the A major chord. From there it is a simple matter to omit the remainder of the modulation and establish this A major chord as the tonic.

Unfortunately, this rationale cannot be used when the two keys are reversed, as they are in the change from A major in the second movement to $\mathrm{C}$ major in the last movement. As a result, Kollmann is in the unpleasant position of either having to argue against one of the composers whose style he has previously indicated is worthy of emulation or to sanction a progression for which he can offer no justification. He chooses the former course: ${ }^{9}$

The second case is in the same Sonata, where the second movement ends in A major, and the third one begins in $\mathrm{C}$ major, which as it is too great a skip in harmony, ought not to be imitated by young composers.

On the surface it might appear that another work in the group of three trios that Kollmann discusses would offer a still greater challenge. In Hob.XV:29 the movements are in the keys of $\mathrm{E} b, \mathrm{~B}$, and $\mathrm{E} b$, respectively. The keys of the three movements, then, are not merely third related but enharmonically third related (i.e., B major in the second movement is the enharmonic equivalent of $\mathrm{Cb}$ ). Kollmann's discussion continues: 10

The third and fourth case is in Sonata III, where the first movement is in E-flat major, the second in B (or C-flat) major, and the third in E-flat major again. Both of these changes are very good, according to the rules mentioned just now.

9 Ibid.

10 Ibid. 
Clearly Kollmann is in error, since his concept of "abrupt modulation by omission" cannot be applicable in this instance (i.e., neither B nor $\mathrm{Cb}$ can be a diatonic triad in the key of $\mathrm{E} b$ ). This seems, on the surface, to be a stunning example of a theorist simply ignoring a procedure that he is unable to explain. At the same time, however, Kollmann's ready acceptance of an enharmonic reinterpretation of B as C-flat suggests the beginnings of a new rationale: that the key of the second movement is derived from the parallel minor of the tonic, eb. This new rationale resembles Schenker's theory of mixture or combinations if Schenker's original theories can be extended to apply to a new structural level, that is, if mixture can be applied not only to large key areas within the movement but also to the tonalities of movements within the cycle.

In his article on tonal organization in the music of Franz Liszt, Howard Cinnamon employs the concept of mixture to describe three different but related procedures.11 "Primary mixture," the exchange of pitches or triads between parallel keys, corresponds to "combinations" as the term is used in Elizabeth Mann Borgese's familiar English translation of Schenker's Harmony.12 To this initial stage of mixture Cinnamon adds two additional stages that are described by Schenker in passages that are omitted from Borgese's translation. "Secondary mixture" describes triads (or their prolongations) in which the root is diatonic but in which the triad's quality is reversed-for example, the appearance of an A major triad in the key of C major. ${ }^{13}$ Finally, "double mixture" refers to "the application of secondary mixture to a harmony that itself resulted from primary mixture or within the

11 Howard Cinnamon, "Tonic Arpeggiation and Successive Equal Third Relations as Elements of Tonal Evolution in the Music of Franz Liszt," Music Theory Spectrum 8 (1986), p. 2, n. 3.

Heinrich Schenker, Harmony, Oswald Jonas, ed., Elizabeth Mann Borgese, trans., (Cambridge, Massachusetts: MIT Press, 1973), pp. 84-115.

13 Cinnamon, Op cit., p. 2. Passages from Schenker's original text in which these additional stages of mixture are discussed are made available in English translation in the article by Matthew Brown cited above. 
prolongation of a harmony so derived," 14 for example, the appearance of an eb minor triad in the key of $\mathrm{C}$ major.

The terminology used to discuss these procedures in recent writing has been inconsistent. The Borgese translation of Harmony describes only Cinnamon's "primary" mixture. Felix Salzer describes "mixture" and "double mixture" in Structural Hearing but does not mention Cinnamon's "secondary mixture."15 Aldwell and Schachter, however, use the terms "simple mixture," "secondary mixture," and "double mixture", respectively, in Harmony and Voice Leading to describe the three types of mixture mentioned by Cinnamon. ${ }^{16}$ In Kostka and Payne's popular textbook Tonal Harmony the terms "chromatic mediant" and "double chromatic mediant" are used to describe the relationships that Cinnamon calls "secondary mixture" and "double mixture" respectively. To complicate the issue still further, Kostka and Payne do mention "secondary mode mixture" but this term is used to refer to mixture associated with secondary harmonic functions (e.g., to account for the lowered seventh in vii07/V). ${ }^{17}$

It is the contention of this study that Haydn's use of third-related keys reveals an understanding in principle of these forms of mixture, albeit with certain modifications. This observation is not particularly novel where Schenker's first stage of mixture (i.e., "primary" or "simple" mixture) is concerned. In her article "Tonal Exploitation in the Later Quartets of Haydn," Louise Cuyler calls attention to Haydn's bi- modal

$14 \quad$ Ibid., p. 2.

15 Felix Salzer, Structural Hearing, (New York: Dover Publications Inc., 1952) pp. 178-181.

Edward Aldwell and Carl Schachter, Harmony and Voice Leading (New York: Harcourt, Brace, Jovanovich, Inc., 1979), pp. 187-191.

17 Stefan Kostka and Dorothy Payne, Tonal Harmony (New York: Alfred A. Knopf, Inc., 1984). The "chromatic mediant" relationship is described on pp. 303 and 409, the "double chromatic mediant" relationship is described on p. 432, and "secondary mode mixture" is described on p. 333. 
interpretation of the tonic. ${ }^{18}$ Cuyler suggests that any scale in Haydn's usage encompasses a set of pitches that includes both the major and minor forms of the tonic.

This study would expand Cuyler's concept further to suggest that, where key relationships are concerned, Haydn treats all keys as if they were interchangeable with their opposite parallel forms. In the piano trio Hob.XV:27, then, the change from $C$ major in the first movement to $\mathrm{A}$ major in the second movement does not require an elaborate explanation based on fifth- relations, as Kollmann attempts, because to Haydn the key of A includes both its major and minor forms and the latter is a closely-related key to C major. Similarly, in Hob.XV:29 the tonic of the cycle as a whole, $\mathrm{E}$, includes in Haydn's usage its parallel minor, to which the enharmonic equivalent of the second movement is closely related.

Haydn's substitution of one mode for its opposite parallel form could be called modal interchange. Figures 1 and 2 diagram all key relationships that are possible in a system in which modulations are confined to closely-related keys but within which all keys are considered interchangeable with their opposite parallel forms. ${ }^{19}$

18 Louise E. Cuyler, "Tonal Exploitation in the Later Quartets of Haydn," Studies in Eighteenth-Century Music: a Tribute to Karl Geiringer on His Seventieth Birthday (New York: Da Capo Press, 1979), p. 138.

19 Figure 1 is adapted from a similar table found in Kostka and Payne, Op cit., p. 339. 
Mode

Interchange
Mode

Interchange

E $x \quad e-G$

$8-B^{b} \times b^{b}$

A $\quad x \quad a-c^{\prime} \times$ Mode Interchange $x c^{\prime}-E^{b} \quad x \quad e^{b}$

D $x$ d $-F$

$f-A^{b} \quad x \quad a^{b}$

Figure 1.

\begin{tabular}{|c|c|c|c|c|}
\hline $\begin{array}{c}\text { Key of Cycle: } \\
\text { C }\end{array}$ & \multicolumn{2}{|c|}{$\begin{array}{l}\text { No Interchange } \\
\text { of Mode } \\
\text { Key } 2\end{array}$} & \multicolumn{2}{|c|}{$\begin{array}{l}\text { Interchange } \\
\text { of Mode } \\
\text { Key } 2\end{array}$} \\
\hline $\begin{array}{l}\text { No Interchange } \\
\text { of Mode } \\
\text { Key } 1\end{array}$ & G & $\begin{array}{l}\text { e } \\
\text { a } \\
\text { d }\end{array}$ & $\begin{array}{l}\mathrm{g} \\
\mathrm{c} \\
\mathrm{f}\end{array}$ & $\begin{array}{l}\mathrm{E} \\
\mathrm{A} \\
\mathrm{D}\end{array}$ \\
\hline $\begin{array}{l}\text { Interchange } \\
\text { of Mode } \\
\text { Key } 1\end{array}$ & $\begin{array}{l}\mathrm{g} \\
\mathrm{c} \\
\mathrm{f}\end{array}$ & $\begin{array}{l}B^{b} \\
E^{b} \\
A^{b}\end{array}$ & G & $\begin{array}{l}b^{b} \\
e^{b} \\
a^{b}\end{array}$ \\
\hline
\end{tabular}

Figure 2. 
Figures 1 and 2 show that if there is no modal interchange involving either key 1 (i.e., the original key) or key 2 (the goal of the key change), then the tonality of the latter is restricted to the five closely-related keys. If modal interchange is applied to key 1 , taking $C$ major as an example, the range of possibilities consists of keys that stem from Schenker's first stage of mixture (i.e., simple or primary mixture). These include $\mathrm{c} \mathrm{mi-}$ nor and all of its closely-related keys. If key 2 is subjected to modal interchange, the range of possibilities consists of keys which are derived from the second stage of mixture described above (i.e., secondary mixture) and includes keys whose parallel forms are closely related to $\mathrm{C}$ major. To take this line of reasoning to its ultimate logical conclusion, relationships might be considered in which modal interchange is applied both to key 1 and to key 2 . This process might be called double modal interchange since in such cases the relationship derives from Schenker's third stage of mixture (i.e., double mixture). As Figure 2 indicates, the range of possible key relationships includes all keys that have an opposite form that is a key closely-related to C major's opposite form.

This system can be tested and refined by comparing the key relationships possible in Figure 2 with key relationships that are found in Haydn's works. This comparison reveals that Haydn's usual practice is to use only key relationships in which there is a common tone between tonic of the cycle as a whole and the tonic of a deviant movement. For example, the ascending and descending major second relationship (e.g., C to D or C to Bb) is not used in Haydn's works while the theoretically more distant ascending and descending major third relationship (e.g., $C$ to $E$ or $C$ to $A$ b) occurs in several examples.

By tracing the evolution of Haydn's use of third-related keys in his instrumental works one can gain some sense of how Haydn's thinking about these key relationships might have developed. The following survey considers three major groups of Haydn's instrumental music: the solo and ensemble keyboard works, the string quartets, and the symphonies. Three general observations can be made: 1) abrupt shifts to third-related keys were used within movements, and particularly near the beginnings of the development sections of sonata forms, before these key relationships appear between movements of the cycle, 2) there is usually some attempt to prepare the listener for the appearance of a 
third-related key by means of brief reference to that key in the course of some section that is normally tonally unstable (for example, the transition section of a sonata form), and 3) the earliest uses of thirdrelated keys involve a bi-modal interpretation of the tonic of the cycle as a whole rather than a bi-modal interpretation of the tonic of the deviant movement.

Haydn's symphonies of the 1770's and 1780's are a good place to begin a survey of the composer's treatment of third-related keys. One of Haydn's early uses of a prominent third relationship is found near the beginning of the development section of the fourth movement of the Symphony No.71 (Figure 3).

This movement begins in the key of $\mathrm{B} b$ and modulates to the key of $\mathrm{F}$ before the double bar. The development section begins in the key of $\mathrm{Db}, \mathrm{b} \mathrm{VI}$ in the key of $\mathrm{F}$. Unlike later examples, there is no preparation for this key earlier in the movement. Apparently Haydn was uncertain about this bold new key relationship. In various eighteenth-century editions the words "per licentiam" or "con permissione" are printed in the score precisely at this point. In a conversation with his biographer A. C. Dies, Haydn explained his use of this expression, ${ }^{20}$ claiming that he often:

... took the liberty not of offending the ear, of course, but of breaking the usual textbook rules, and wrote beneath these places the words con licenza. Some cried out, "A mistake!" and tried to prove it by citing Fux. I asked my critics whether they could tell by ear that it was a mistake? They had to answer No.

20 A.C. Dies, Biographische Nachtrichten von Joseph Haydn in Vernon Gotwals, ed. and trans. Haydn: Two Contemporary Portraits (Madison, Wisconsin: The University of Wisconsin Press, 1968), p. 109. 

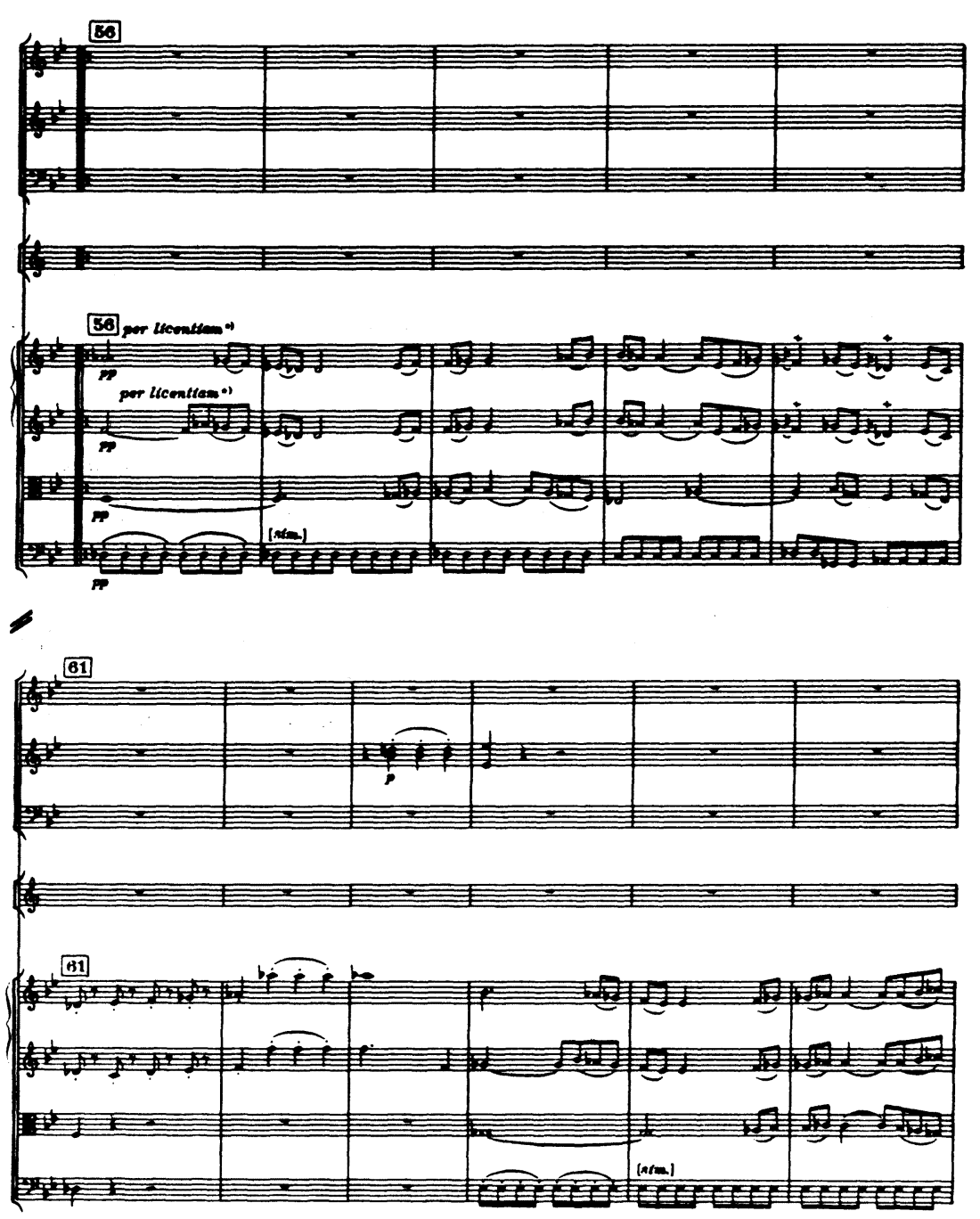

1) Whon Nan. "eon pormileatione"

Figure 3. : Haydn. Symphony No. 71 in Bb, IV, mm. 56-66. 
Expressions similar to this occur in other late works by Haydn in contexts that are clearly related to imaginative harmonic treatment. For example, the letters "c: l:" or the words "cum licentia" are found at such points in contemporary editions of some of the late quartets, in particular Op.76 No.6.21

Haydn's next important use of a third-related key in the symphonies is found in the Symphony No.78, which was written about two years after No.71.22 In the first movement the exposition begins in $c$ minor and modulates to the relative major. The development section begins in the key of Db just as in Symphony No.71 (Figure 4).

In the present example, however, the key of $\mathrm{Db}$ is introduced by four measures in which the key of $\mathrm{f}$ minor is tonicized, a clear statement concerning the derivation of the key of $\mathrm{D} b$ in the area that follows (i.e., $\mathrm{D} b$ is $\mathrm{VI}$ in $\mathrm{f}$ minor).

In addition to passages that serve to prepare for the appearance of a distant key, there are instances in the symphonies in which a third relationship is "explained" (i.e., the derivation of the distant key is clarified) by passages that appear after the actual key change. An example of this sort is found in the third movement of Symphony No.78 (Figure 5).

$21 \quad$ Landon, Op cit., vol. 4, p. 307, n. 1.

22 H.C. Robbins Landon, Haydn: Chronicle and Works, Vol. 2, Haydn at Eszterhaza 1766-1790 (Bloomington, Indiana: Indiana University Press, 1978), Landon dates Symphony No. 71 from 1779-1780 (p. 561), although he indicates that some evidence suggests the first movement may have been written before the remainder of the work; No. 78 is dated 1782 (p. 564). 
[71]

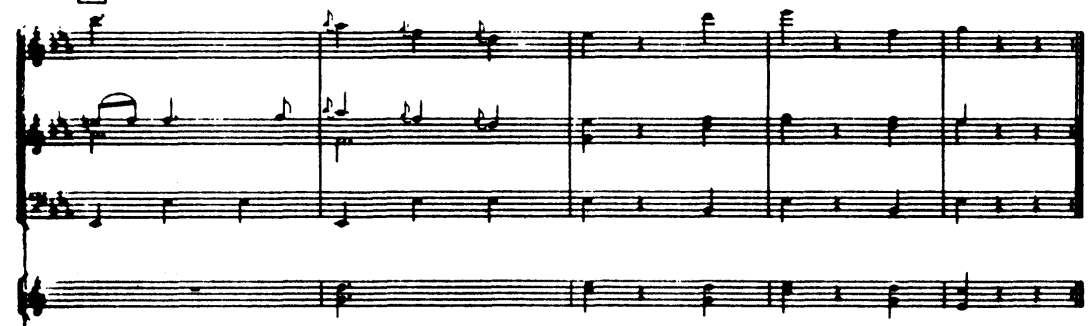

[71]
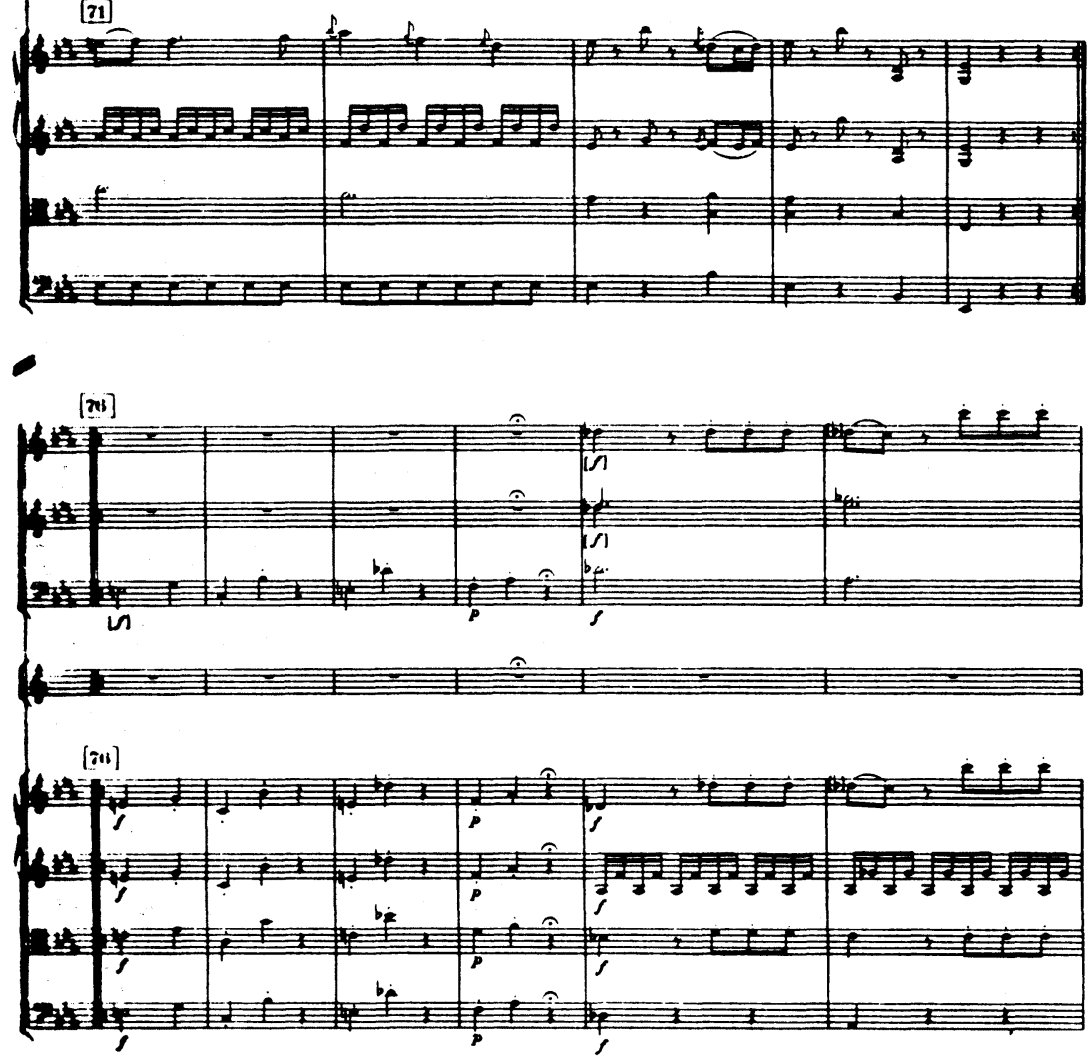

Figure 4. : Haydn, Symphony No. 78 in c, I, mm. 71-81. 

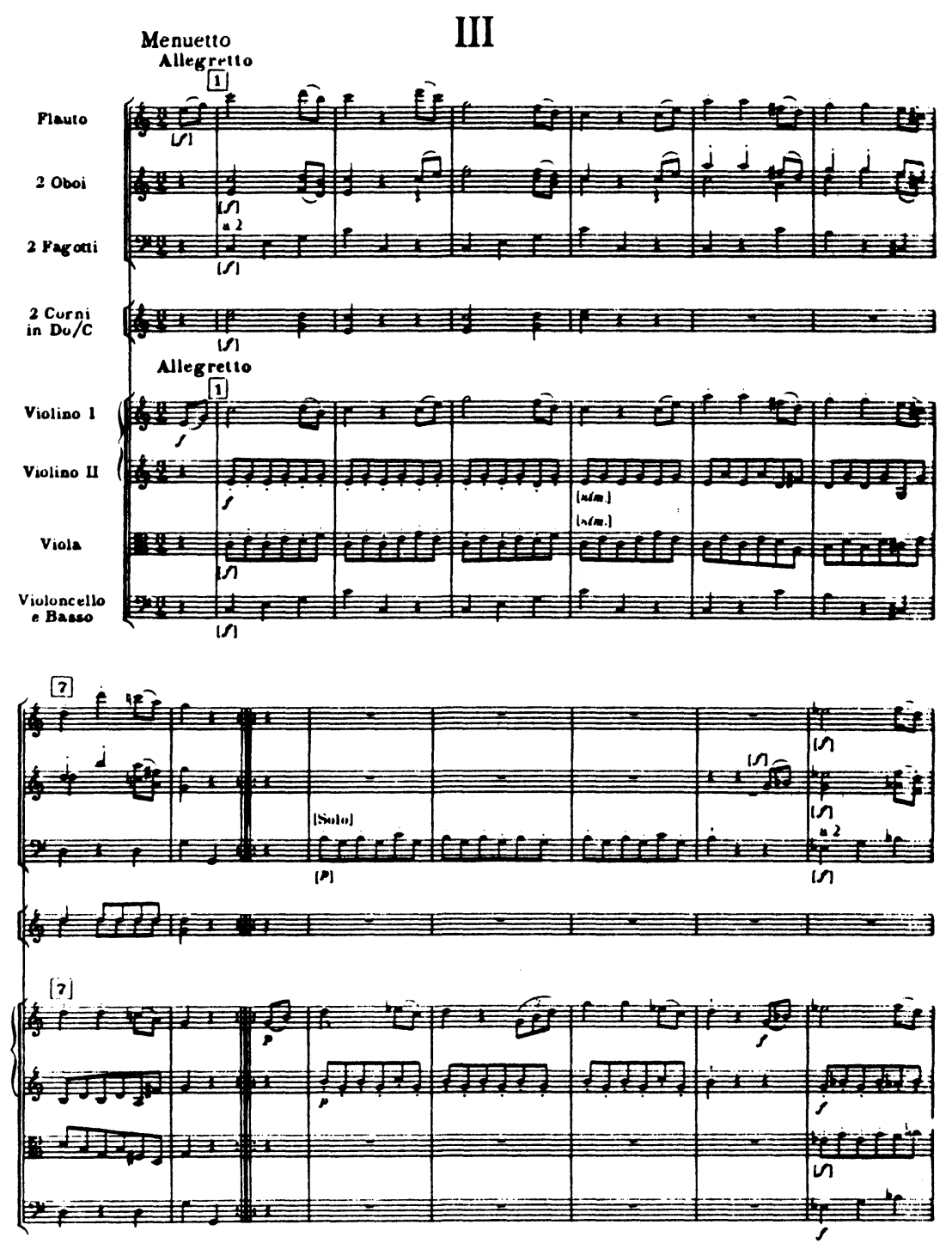
[14]

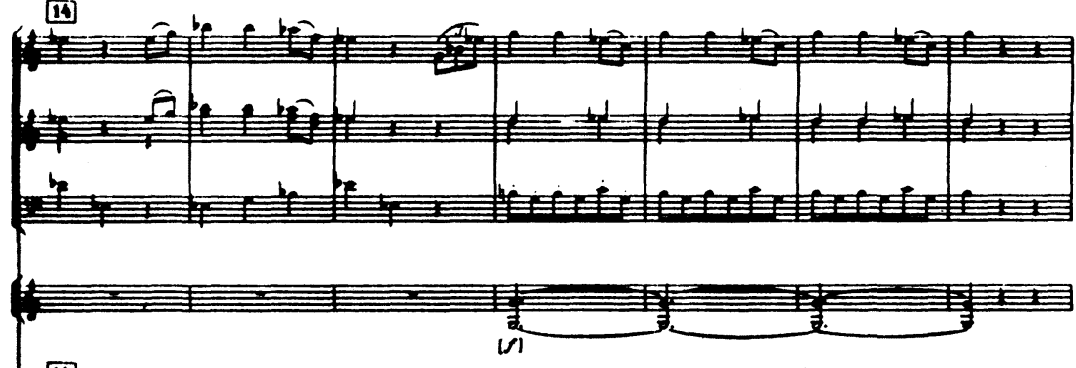

[14]

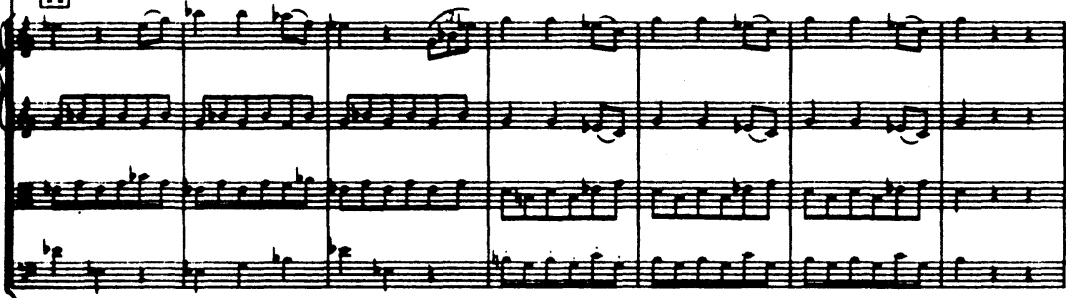

[2i]

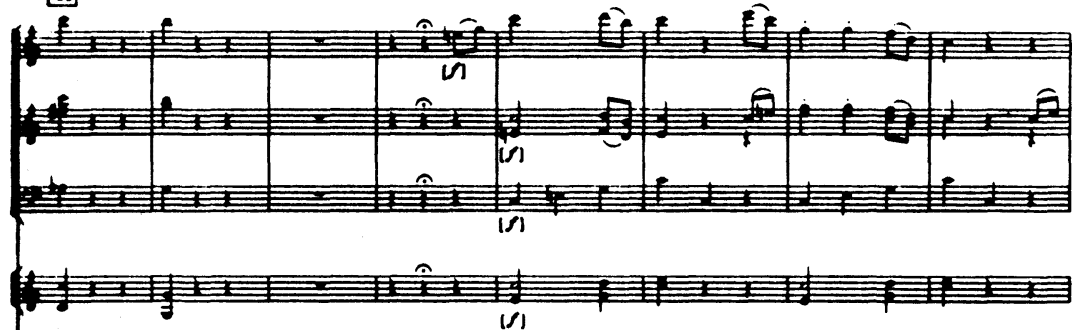

[3i]

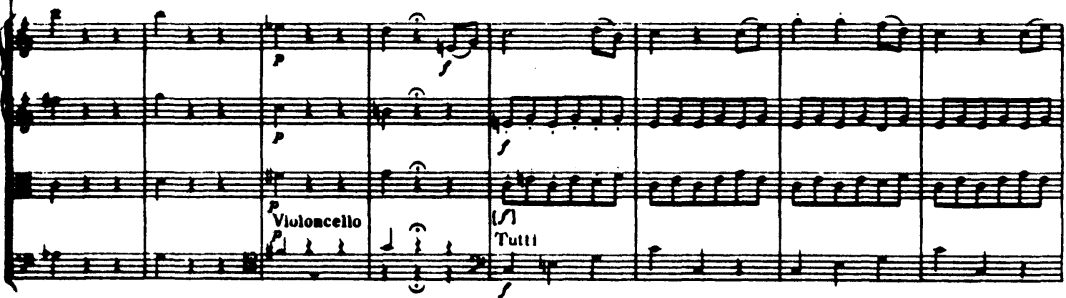

Figure 5. : Haydn, Symphony No. 78 in c, III, mm. 1-28. 
This minuet begins in the key of $\mathrm{C}$ major while the second movement is in the key of $\mathrm{Eb}$ (the latter being a closely-related key to the tonic of the cycle as a whole (c minor) but having a more distant relationship with respect to the key of $\mathrm{C}$ major in the third movement). The second strain of the minuet begins in $\mathrm{c}$ minor but shifts abruptly to the key of $\mathrm{Eb}$ in measure 13. This use of $\mathrm{c}$ minor is, in effect, a reminder of the bi-modality of the key of $\mathrm{C}$ which serves to explain the juxtaposition of the keys of $\mathrm{E} b$ and $\mathrm{C}$ between the second and third movements.

In the first movement of Symphony No.80, which was written around $1783-1784,23$ there is yet another passage in the key of $D b$ at the beginning of the development section. In this case the key of $\mathrm{Db}$ is prepared by a reference to $\mathrm{D} b$ in the transition section, which modulates from the key of the tonic, $d$ minor, to the second key area, F major (Figure 6).

To summarize, then, all of the examples considered up to this point exemplify Schenker's first stage of mixture, usually involving the tonicization of bVI in major. In all but the first somewhat tentative example there is an obvious attempt to make clear the derivation of the foreign key. In the earliest example in which the new key is prepared (Symphony No.78) this preparation occurs immediately prior to the inodulation. In even slightly later examples, however, Haydn's preparation is more subtle and often occurs further away from the actual key change. Finally, the earliest examples of Haydn's uses of third-related keys in the symphonies occur within individual movements, but this technique is soon (in Symphony No.78) extended to key relationships between movements.

Landon, Op cit., Vol. 2, p. 565. 
Figure 6
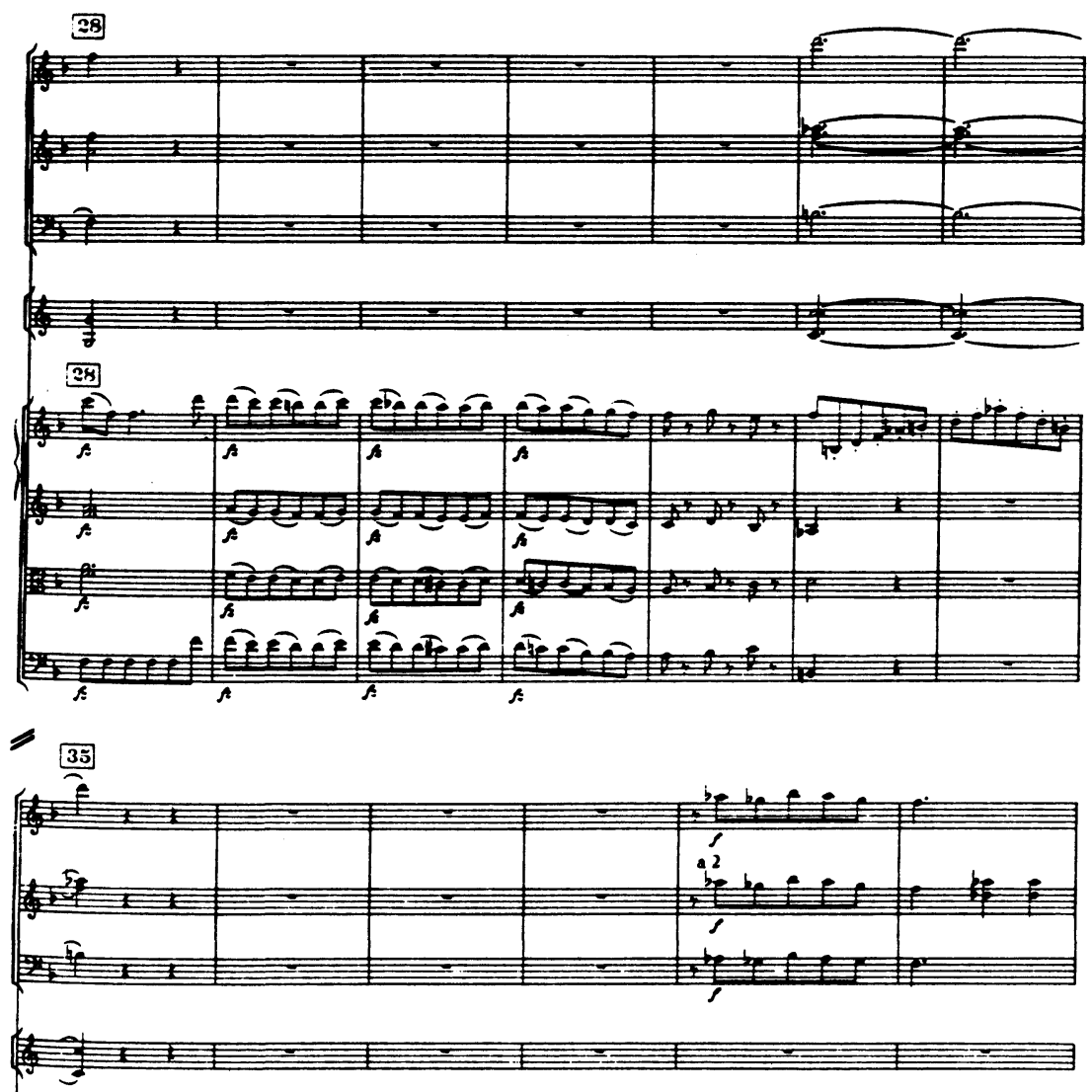

30

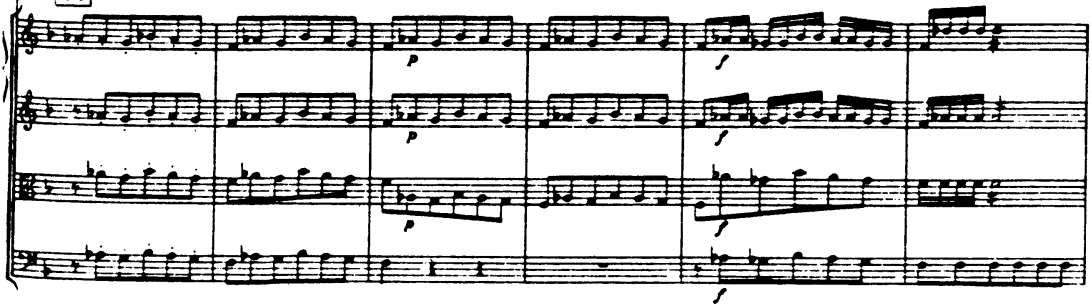


Figure 6 : cont.

[4i]

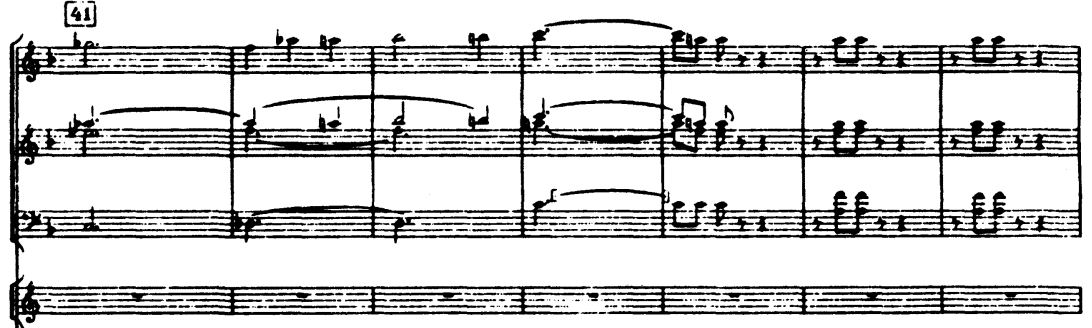

[4]

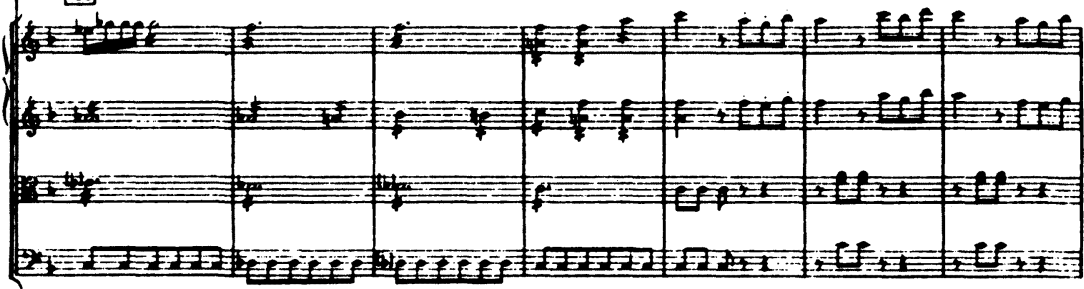

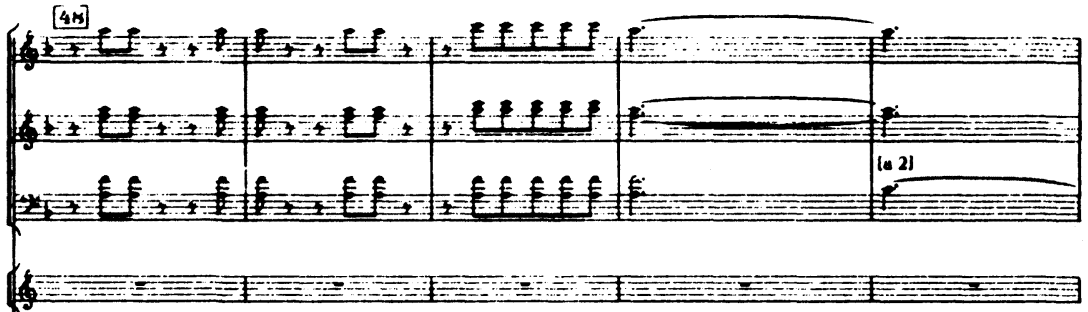

[ix]

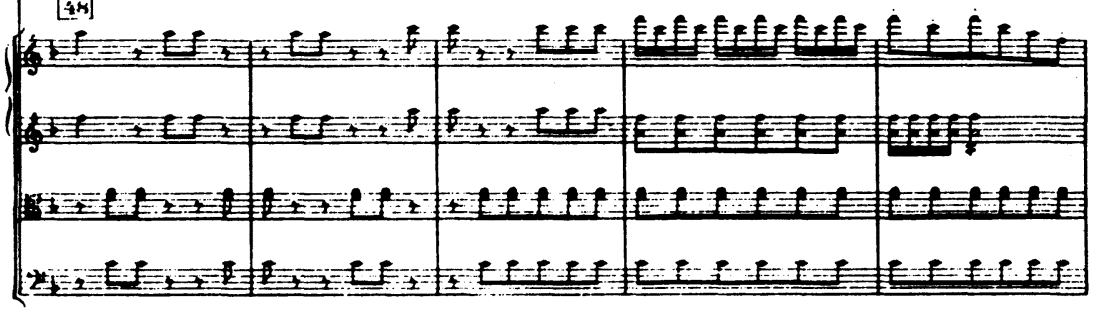


Figure 6 : cont.

[53]

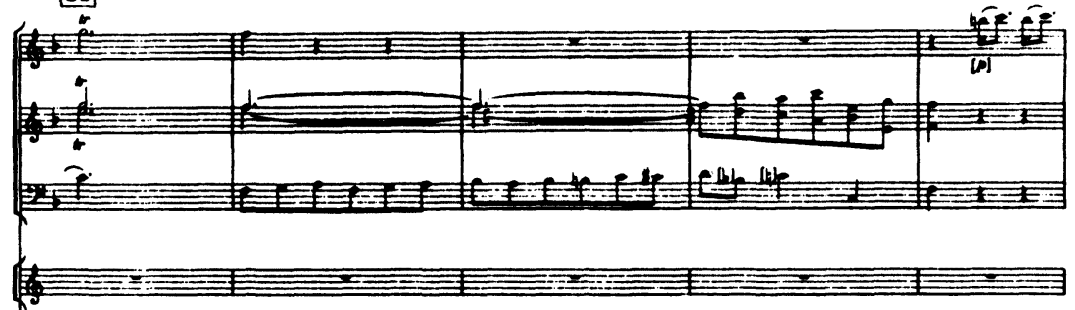

[5:3]

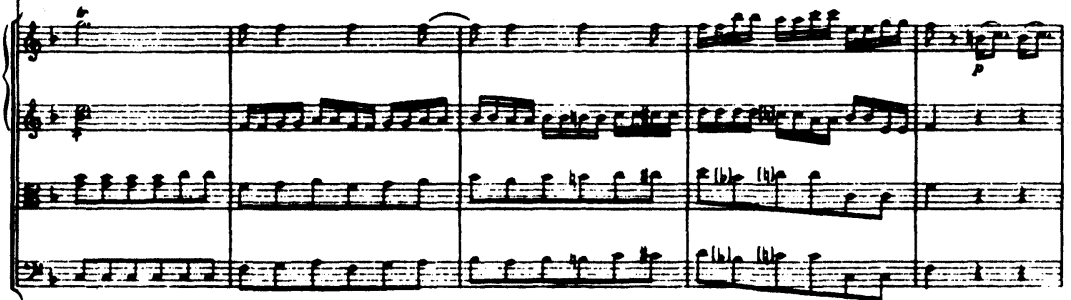

[s]

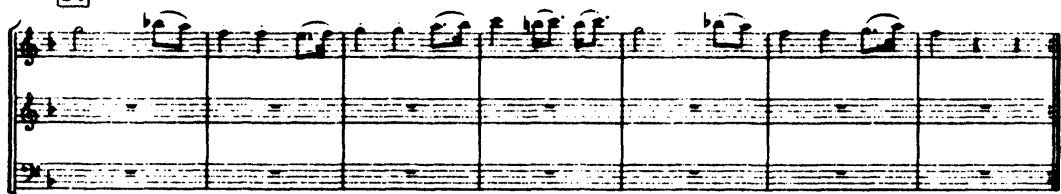

娃

-2 1

[5x]

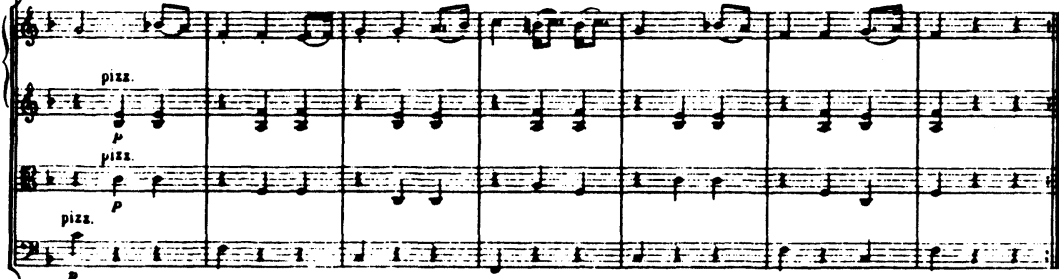


Figure 6 : cont.

60
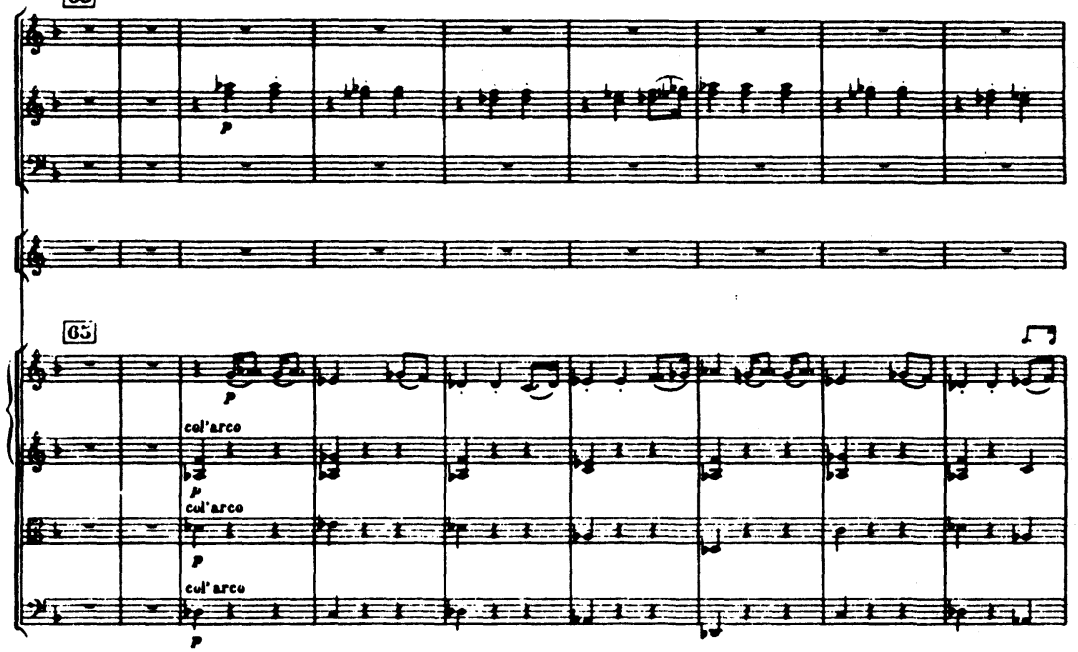

[74]

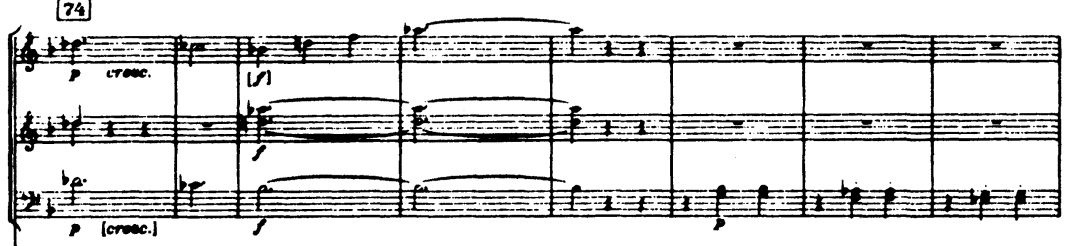

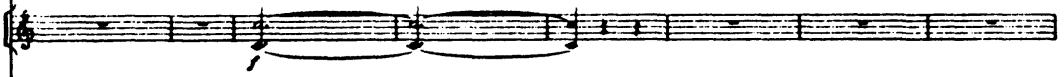

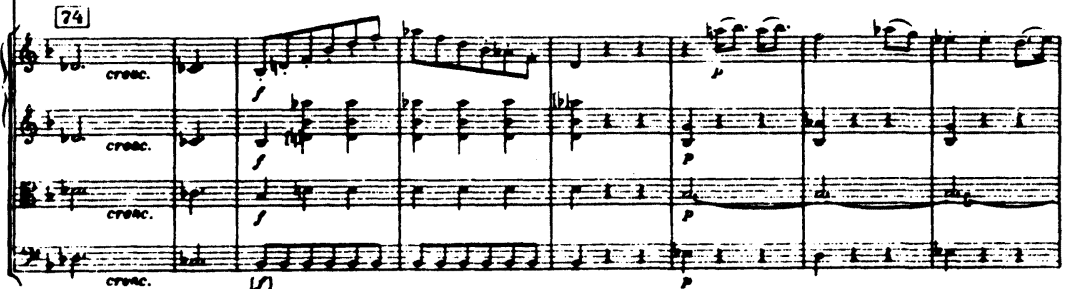




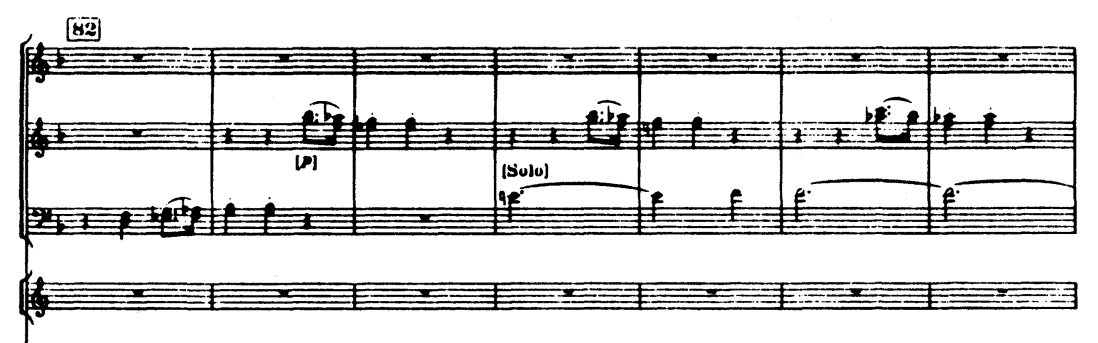

82
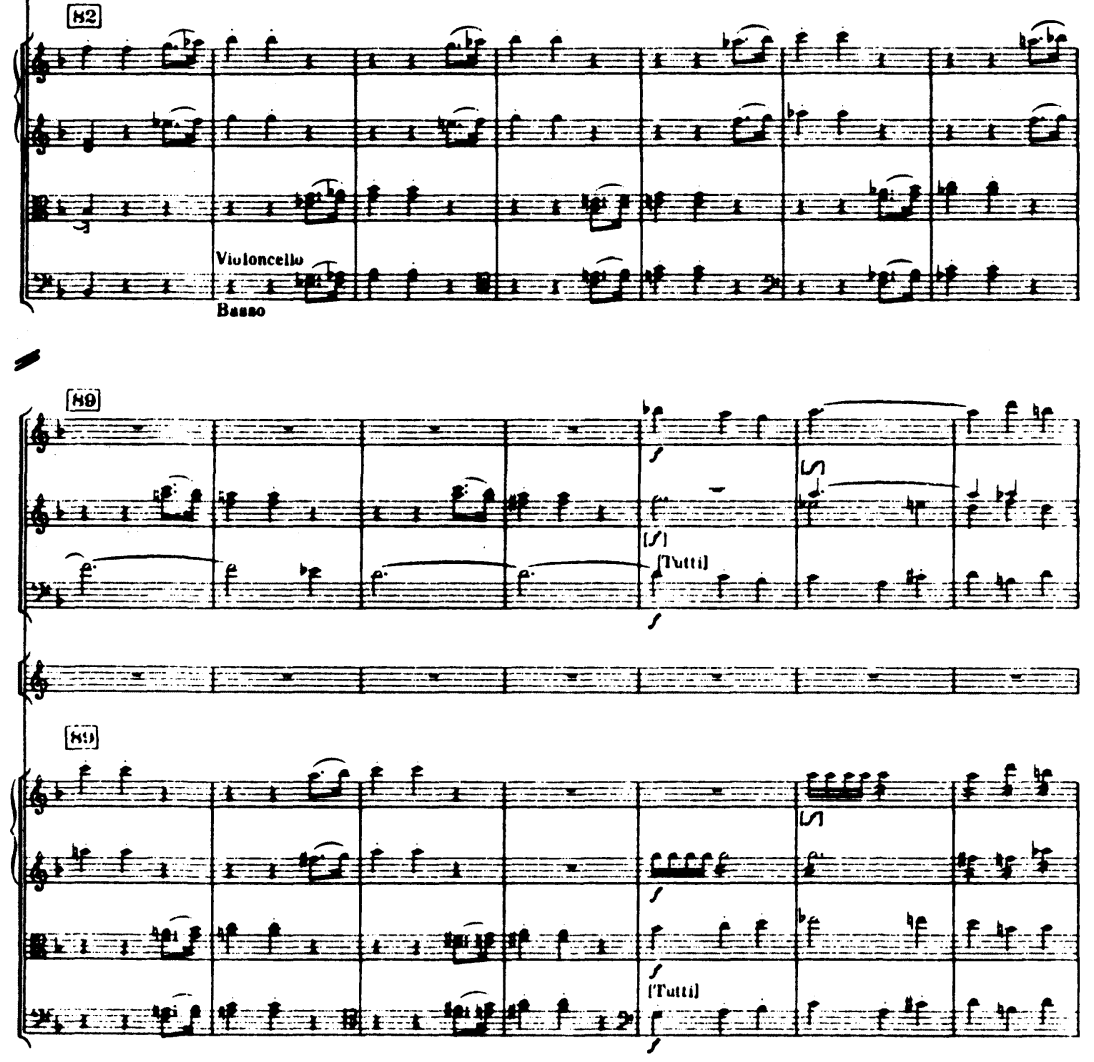

Figure 6. : Haydn, Symphony No. 80 in d, I, mm. 28-95. 
Two further steps remain to be shown in the evolution of Haydn's approach to third-related keys: the use of key relationships which involve a bi-modal interpretation of the second key rather than the first (or, in cases in which an entire movement is in a third-related key, the use of key relationships involving a bi- modal interpretation of the key of the deviant movement rather than the key of the cycle as a whole), and the use of key relations involving the mediant rather than the sub-mediant. These techniques appear primarily in instrumental works which date from the time of the London visits and later.

In the minuet of the Quartet Op.74 No.1 (which dates from 1793) ${ }^{24}$ there is an example of the first of these practices. In this movement the minuet is in the key of $\mathrm{C}$ major and the trio is in A major. The relationship results, then, from Schenker's second level of mixture (i.e., "secondary mixture"). As in other examples an "explanation" is provided after the fact for this key relationship. The trio concludes with a section in a minor (demonstrating the bi-modality of A) that is presented over an "e" pedal (Figure 7) in measures 97-112.

This section in a minor concludes with an unharmonized "e", a pivot tone back to the key of $\mathrm{C}$ for the repeat of the minuet. Keeping in mind Kollmann's difficulty with this key progression in Hob.XV:27, it should be recalled that eighteenth-century theory can account for the key change from $\mathbf{C}$ to $\mathrm{A}$ major, but not the return from $\mathrm{A}$ back to $\mathrm{C}$.

24 H.C. Robbins Landon, Haydn: Chronicle and Works Vol. 3, Haydn in England 1791-1795 (Bloomington, Indiana: Indiana University Press, 1976), p. 455. 


\section{Figure 7}
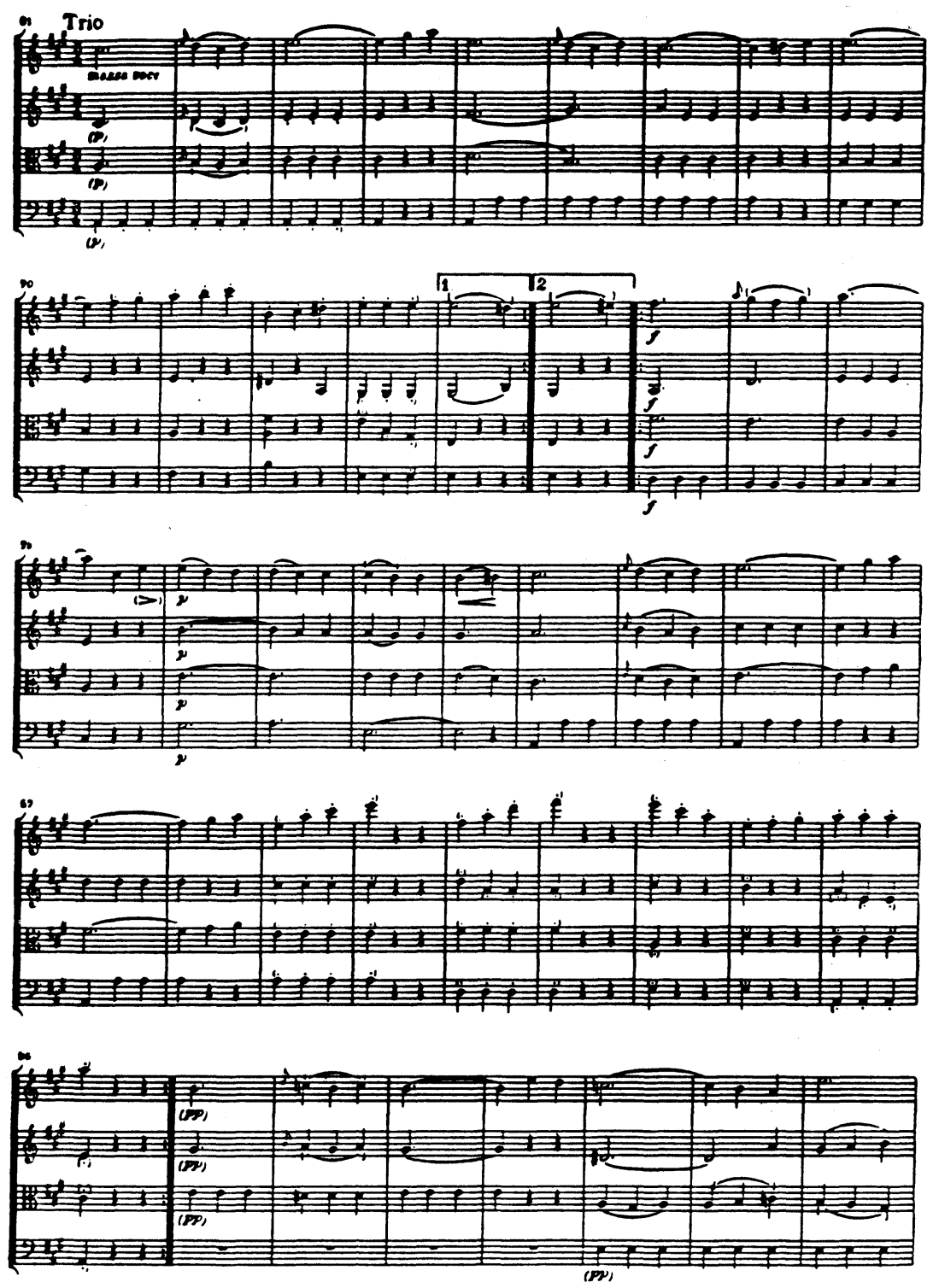


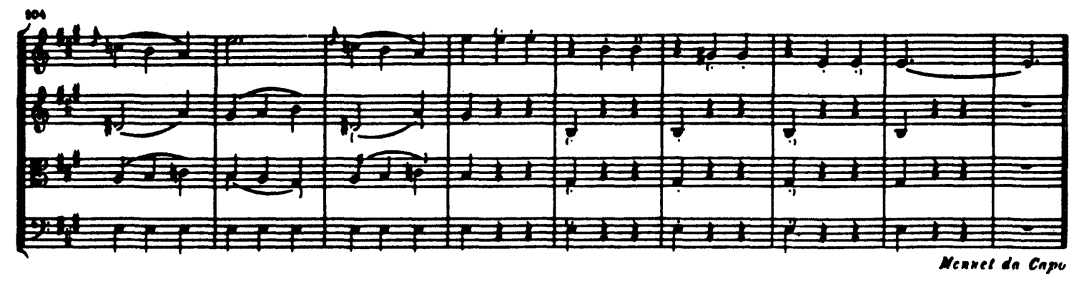

Figure 7. : Haydn, Quartet Op. 74, No. 1, mm. 81-112.

Perhaps this explains Haydn's careful return to the key of $\mathrm{C}$ by way of a minor.

Third-related keys are used as the tonalities of movements in the cycle in six of Haydn's fifteen late piano trios (Hob.XV:20, 22, 25, 27, 29, and 30). With the exception of XV:29, all of these trios have key schemes that result from a bi- modal interpretation of the second key. In XV:20, 25, 27, and 30 the second movement of these threemovement cycles is in the key of the major submediant. In each case there is some sort of preparation for the distant key, usually within the first movement. In general, however, these preparations are more subtle than the corresponding areas in the symphonies of the 1780's. In the development sections of the first movements of XV:20, 27, and 30 there is nothing more than a prominent area in the key of the diatonic submediant. In XV:30, in which the three movements are in the keys of $E b, C$ and $E b$ there is an additional "explanatory" passage at the end of the second movement (Figure 8).

Apparently Haydn felt the need to introduce c minor elements near the end of the second movement in order to make more clear the relationship between the keys of the $\mathrm{C}$ and $\mathrm{Eb}$. This is done by means of a modification of the usual deceptive cadence formula in which the submediant is replaced by bVI $(\mathrm{A} b)$. 

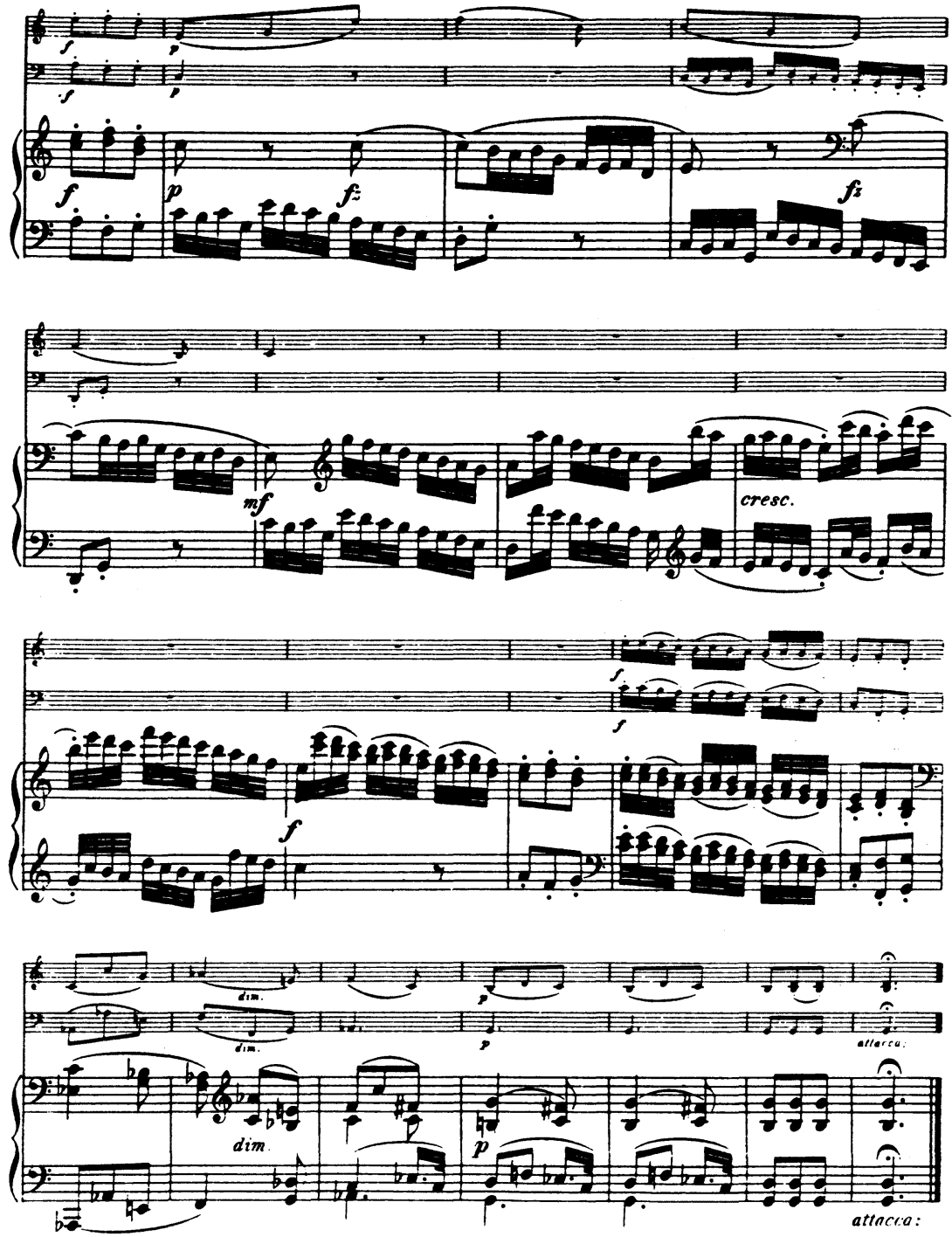

Figure 8. : Haydn, Piano Trio Hob. XV:20, II, mm. 95-114. 
In XV:25 and XV:29 the first movements contain more specific preparations for the distant keys of the second movements. The first movements of both cycles are double variations in which there are two themes on the same tonic but in opposite modes with alternating variations of each theme. In XV:29, in which the two themes are in $E_{b}$ major and eb minor, the second theme does not remain in eb minor throughout. Instead of modulating to the relative major of eb minor as might be expected, however, this second theme modulates to $\mathrm{Cb}$ major, bVI of the original tonic (Figure 9).

The key of B in the second movement, then, is specifically prepared. Perhaps it is this preparation that caused Kollmann so easily to accept the complex key scheme of this work.
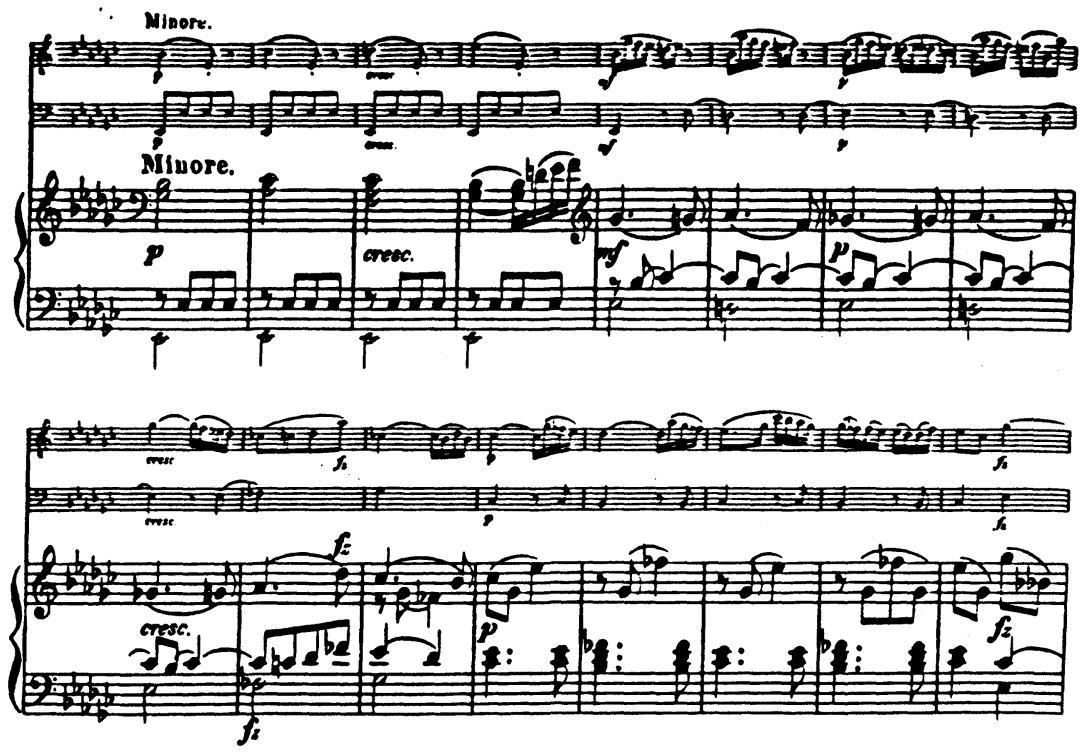

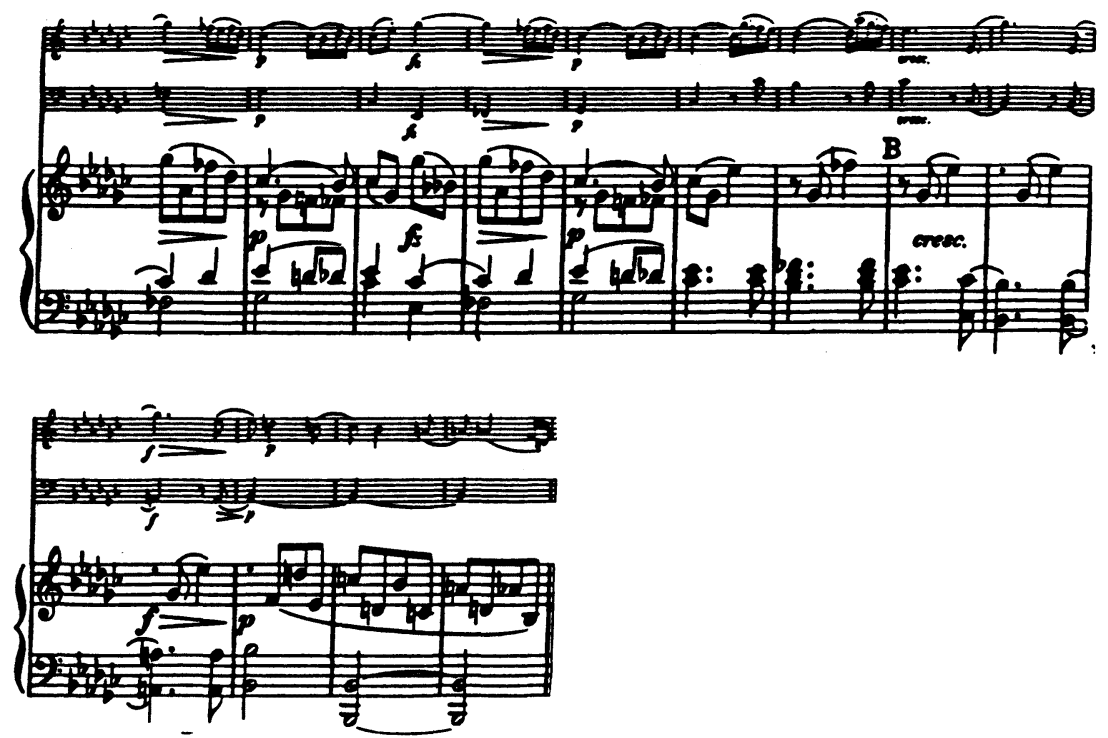

Figure 9. : Haydn, Piano Trio Hob. XV:29, I, mm. 51-79.

In XV:25 there are two themes in $\mathrm{G}$ major and $\mathrm{g}$ minor respectively. One of the variations of the second theme is in the key of the submediant, e minor, a remarkable departure from Haydn's usual practice of at least beginning each variation in the key of the tonic. In this way the key of the major submediant, E, in the second movement is prepared.

Thus far the examples presented exemplify either Schenker's first or second stages of mixture (i.e., "primary" or "secondary" mixture). But are there any examples of "double" mixture in the works of Haydn, or, in the terminology of modal interchange, are there examples in which the opposite form of the first key is a related key to the opposite form of the second key? Examples of this are found in Haydn's operas, which lie outside the scope of this paper, but few are found in the instrumental works. An apparent example of this practice is found in the quartet Op.74 No.3, in which the four movements are in g, E, G, and $\mathrm{g}$, respectively. In this case the key of the second movement has 
an opposite form, e minor, that is a closely-related key to the opposite form of the tonic of the cycle as a whole, $G$ major. In reality, however, the first movement of this cycle begins in $\mathrm{g}$ minor but concludes in the key of $\mathrm{G}$ major, thus there is no point at which the keys of $\mathrm{g}$ minor and E major are juxtaposed.

The quartet Op.74 No.3 illustrates a point made above: that Haydn's usual practice is to confine tonal relationships to keys in which a common tone exists between the tonic of the first key and the tonic of the second key. There are exceptions to this general rule, however. In the well-known piano sonata Hob.XVI:52 the three movements are in the keys of $\mathrm{Eb}, \mathrm{E}$, and $\mathrm{Eb}$. Even this most unusual key relationship can be explained as a form of modal interchange if one keeps in mind Haydn's tendency to offer "explanations" for unusual key relationships. In this case the explanation comes in the first movement near the end of the development section (Figure 10).
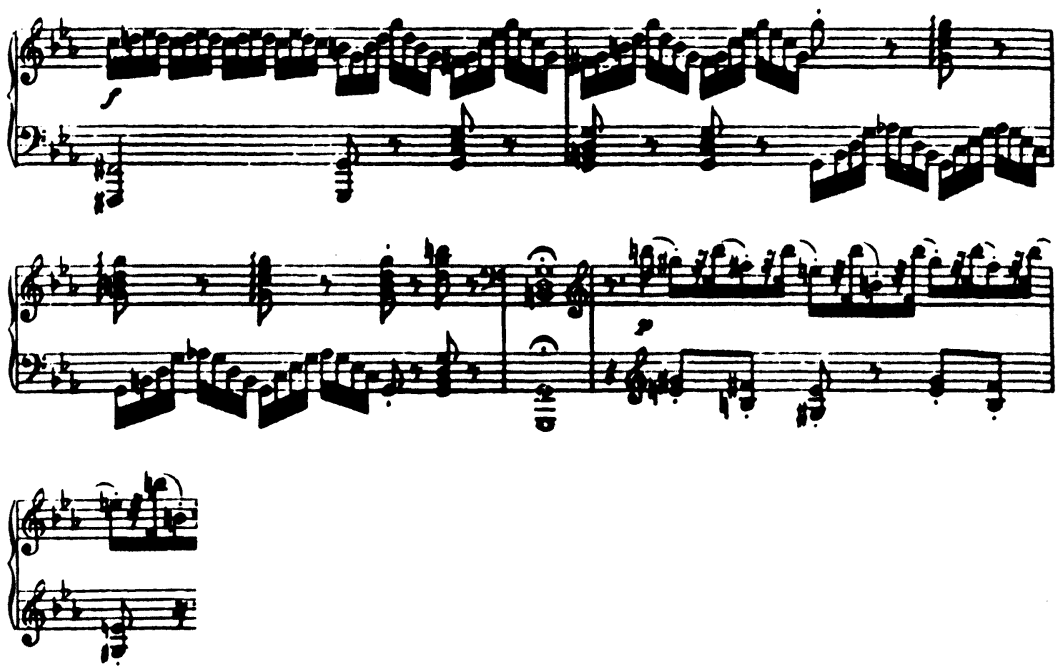

Figure 10. : Haydn, Piano Sonata in Eb, Hob. XVI/52, I, mm. 65-70 
Here a tonicization of the key of the relative minor, c, ends in a half cadence in measure 68 that is followed by a passage in the key of $\mathrm{E}$ major. This is an example, then, of double modal interchange in that the opposite form of $\mathrm{c}$ minor - the prevailing tonic - is a related key to the opposite form of the new key. The connection between the key of the tonic and the key of the second movement is less clear. To some this may seem to be a simple case of Phrygian mixture (spelled enharmonically), a type of mixture described by Schenker in Harmony. Keeping in mind example 10, however, perhaps this is a case in which it is not the parallel minor of the first key that is related to the parallel minor of the second key but rather it is the opposite form of the relative minor that is related to the opposite form of the second key.

This may appear to be a complex rationale, but the individual steps of the process, taken separately, are reasonable. Since Haydn has shown in the development section of the first movement that the keys of $\mathrm{c} \mathrm{mi-}$ nor and $\mathrm{E}$ major may be juxtaposed, it is a reasonable step to substitute $\mathrm{Eb}$ major for its relative minor. In other words, if $\mathrm{E} b$ major is considered to be interchangeable with $\mathrm{c}$ minor, $\mathrm{c}$ minor is interchangeable with $\mathrm{C}$ major, $\mathrm{C}$ major is related to e minor, and e minor is interchangeable with $\mathrm{E}$ major, then it is reasonable for $\mathrm{E} b$ major to proceed to E major.

In summary, eighteenth-century theories of key relationship based on fifth relations are not adequate for an explanation of Haydn's music. Kollmann's discussion in particular reveals an obvious flaw in this line of reasoning. Moreover, his comments are entirely concerned with an intellectual justification for a process he does not adequately explain and seem unrelated to the aural effect of the music. If Kollmann is prepared to accept the sound of the juxtaposition of the keys of $\mathrm{C}$ and $A$ in that order, it hardly seems reasonable to exclude these keys in the reverse order - in which they present a relationship that is no more distant aurally-merely because they do not conform to the fragile edifice of logic he has constructed. In Haydn's case, on the other hand, it is clear from his remarks to Dies that sound is his principle concern and not the artificial distinctions of eighteenth-century theorists. 


\section{REFERENCES}

ALDWELL, EDWARD \& SCHACHTER, CARL.

1979: Harmony and Voice Leading. New York: Harcourt, Brace, Jovanovich, Inc.

BROWN, MATTHEW.

1987: "The Diatonic and the Chromatic in Schenker's Theory of Harmonic Relations," Journal of Music Theory, 30: 1-33.

CINNAMON, HOWARD.

1986: "Tonic Arpeggiation and Successive Equal Third Relations as Elements of Tonal Evolution in the Music of Franz Liszt," Music Theory Spectrum 8: 1-24.

CUYLER, LOUIS E.

1979: "Tonal Exploitation in the Later Quartets of Haydn," in Studies in Eighteenth-Century Music: A Tribute to Karl Geiringer on his Seventieth Birthday. New York: Da Capo Press, pp. 136-150.

DIES, A.C.

1968: Biographische Nachtrichten von Joseph Haydn in Vernon Gotwals, ed. and trans. Haydn: Two Contemporary Portraits. Madison, Wisconsin: The University of Wisconsin Press.

KIRNBERGER, JOHANN PHILIPP.

1771-1779/1982: The Art of Strict Musical Composition. translated by David Beach and Jurgen Thym, New Haven: Yale University Press.

KOLLMANN, AUGUSTUS FREDERIC CHRISTOPH.

1799/1973: An Essay on Practical Music Compostion. New York: Da Capo Press.

KOSTKA, STEFAN \& PAYNE, DOROTHY.

1984: Tonal Harmony. New York: Alfred A. Knopf, Inc.

KRAMER, RICHARD.

1985: "The New Modulation of the 1770's: C.P.E. Bach in Theory, Criticism, and Practice," Journal of the American Musicological Society, 38: 551-592.

LANDON, H.C. ROBBINS.

1978: Haydn: Chronicle and Works Vol. 2, Haydn at Eszterhaza 1766-1790. Bloomington, Indiana: Indiana University Press.

1976: Haydn: Chronicle and Works Vol. 3, Haydn in England 1791-1795. Bloomington, Indiana: Indiana University Press.

1976: Haydn: Chronicle and Works Vol. 2, The Years of "The Creation" 1796-1800. Bloomington, Indiana: Indiana University Press. 
PROCTOR, GREGORY.

1977: "Technical Bases of Nineteenth-Century Chromatic Tonality: A Study in Chromaticism," PhD. dissertation, Princeton University.

SALZER, FELIX.

1952: Structural Hearing. New York: Dover Pulications Inc.

SCHENKER, HEINRICH.

1973: Harmony, Oswald Jonas ed. and Elizabeth Mann Borgese, trans., Cambridge, Massachusetts: The MIT Press. [translation of Neue Musikalische Theorien und Phantasien, Bd. 1, Harmonielehre Stuttgart: Cotta, 1906]. 